REVIEW

\title{
Ecology of iron-limited cyanobacteria: a review of physiological responses and implications for aquatic systems
}

\author{
Steven W. Wilhelm* \\ Marine Science Institute, The University of Texas at Austin, 750 Channelview Drive, Port Aransas, Texas 78373, USA
}

\begin{abstract}
Recent studies have demonstrated that cyanobacteria are capable of responding to low levels of iron availability through alterations in cellular iron requirements and by increasing their ability to scavenge iron from the environment through the activation of siderophore-mediated high-affinity transport systems. The significant amount of evidence in the literature on siderophore production by cyanobacteria suggests that these iron-chelating compounds may be important in the determination of iron availability in aquatic systems. This review focuses on how cyanobacteria respond to growthlimiting levels of available iron and on how siderophores potentially alter the biological availability of iron in the system thereby allowing the cyanobacteria to exist at low iron availabilities. In the light of recent findings on the amount of organically complexed iron in aquatic systems, it is concluded that the production of siderophores by aquatic organisms may specifically dictate the levels of biologically available iron in some aquatic systems.
\end{abstract}

KEY WORDS: Cyanobacteria $\cdot$ Iron $\cdot$ Siderophores $\cdot$ Synechococcus

\section{INTRODUCTION}

The paradoxical existence of high nutrient/low chlorophyll (HNLC) oceanic regions has been attributed to the notion that the biological availability of iron in some marine systems may regulate new production. Evidence from Martin and co-workers (Martin \& Fitzwater 1988, Martin et al. 1989, 1990) preceded a flurry of reports suggesting that certain areas of the oceans, including the sub-Arctic Pacific gyre, the equatorial Pacific, and the vast Southern Ocean, may be limited by the amount of available iron. Since then, a considerable effort has been put forth to determine the role of iron in regulating primary productivity, and this work has been comprehensively reviewed by Hutchins (1995) as well as by Geider \& LaRoche (1994).

Of specific recent interest, researchers have focused on the effect of iron limitation on the physiology of cyanobacteria, and the associated high-affinity iron

·E-mail: swilhelm@utmsi.zo.utexas.edu acquisition response during iron-limited growth. While a number of cyanobacterial species have been studied, those of the genus Synechococcus, which dominate many freshwater and marine systems, are perhaps of the most interest. Synechococcus spp. reach high densities in most HNLC regions (Chavez et al. 1991), and recent experiments have suggested that iron availability may not control cyanobacterial productivity in these regions (DiTullio et al. 1993, Wells et al. 1994). This raises the question as to how these cyanobacteria compensate for such low levels of available iron

This review will focus on laboratory studies of cyanobacteria (predominantly Synechococcus spp.) maintained at low iron availabilities and consider the potential influence of these primary producers on aquatic iron cycles and the bioavailability of iron to other organisms in the system. While it is often difficult to extrapolate from the laboratory to in situ environments, laboratory studies provide valuable insight into why cyanobacteria may successfully proliferate in HNLC systems. 


\section{RESULTS AND DISCUSSION}

Despite intense efforts, it remains difficult to determine which forms of $\mathrm{Fe}$ are biologically available and which are unavailable to phytoplankton in aquatic systems (Wells et al. 1995). Due to differences in the strategies of phytoplankton for iron acquisition, what may be available to some species remains unavailable to other species in the same environment. Thus, while the phrase 'biologically available' will be used throughout this paper, it is perhaps best to consider biologically available iron as a collection of biologically accessible sub-groups, which in sum represent the biologically available iron in the system

\section{Eifect of iron availability on cyanobacterial growth}

Laboratory studies on the effect of iron availability on cyanobacterial growth examine 2 questions: the total biomass generated by a given level of iron (maximum yield experiments), and growth rate experiments in which the maximum growth rate $\left(\mu_{\max }\right)$ is calculated for given iron levels. Maximum yield experiments, designed to estimate cellular iron quotas, have been carried out in both batch (Brand 1991, Rueter \& Unsworth 1991) and chemostat cultures (Wilhelm \& Trick 1995a). Cellular requirements are determined by normalizing total iron to cell number or expressed as iron normalized to other cellular components (i.e. N, P, or C). Utilization of a standardized Redfield ratio allows for an intercomparison of results (Table 1). These requirements can be contrasted with those determined through the utilization of a solution of titanium (III)-citrate-EDTA (Hudson \& Morel 1989), which rapidly reduces extracellular iron and allows for a determination of iron within the cell when cells are maintained with tracer levels of ${ }^{55} \mathrm{Fe}$ or ${ }^{59} \mathrm{Fe}$ (Sunda et al. 1991, Wilhelm et al. 1996). In all cases, cyanobacterial Fe requirements are higher than those of eukaryotic algae (Table 1). These high requirements are commonly attributed to cyanobacterial evolution, since the availability of iron would have been significantly higher in the anaerobic conditions under which these organsims evolved (Hutchins 1995). However, the higher iron requirements of cyanobacteria relative to eukaryotic plankton may also be attributed to reduced amounts of iron-poor structural material in the cyanobacteria, which would lead to a proportional increase in the cellular iron requirements (Trick \& Wilhelm 1995).

One of the most interesting responses to iron stress is the change in the $\mu_{\max }$ of many cyanobacteria in response to decreases in extracellular iron concentration. Under iron-replete conditions, many cyanobacteria are capable of maintaining $\mu_{\max }$ in excess of 1 division $\mathrm{d}^{-1}$ (Boyer et al. 1987). The $\mu_{\max }$ decreases for most cyanobacteria as the availability of iron decreases (Fig 1). In several species, this drop is followed by a 'recovery' (increase) in $\mu_{\max }$ as the cells are taken further into iron limitation. This response is not seen in all species however, and some, such as the freshwater filamentous Plectonema boryanum, demonstrate a predictable decrease in $\mu_{\max }$ with decreasing nutrient availability (Fig. 1E). The response of $P$. boryanum is typical of phytoplankton for which nutrient acquisition is diffusion mediated, such as vitamin $\mathrm{B}_{12}$-limited growth of Synechococcus sp. PCC 7002 (Wilhelm \& Trick 1995b). Attempts to explain these iron-regulated growth patterns have focussed on 2 potential mecha-

Table 1 Iron quotients of Synechococcus spp. Cellular iron quotients $\left(Q_{\mathrm{Fe}}\right)$ are converted from literature values to Fe:C (mol:mol) ratios using established Redfield values for C:N:P (106:16:1)

\begin{tabular}{|c|c|c|c|c|}
\hline & Literature $Q_{\mathrm{Fe}}$ & Converted $Q_{\mathrm{Fe}}$ & Protocol & Source \\
\hline \multicolumn{5}{|l|}{ Synechococcus spp. } \\
\hline$\left(10^{-6} \mathrm{M} \mathrm{Fe}\right)$ & $\mathrm{N}: \mathrm{Fe}=600$ & $2.5 \times 10^{-4}$ & \multirow{4}{*}{ Maximum yield } & \multirow{4}{*}{ Rueter \& Unsworth (1991) } \\
\hline$\left(10^{-8} \mathrm{MFe}\right)$ & $\mathrm{N}: \mathrm{Fe}=3000$ & $5.0 \times 10^{-5}$ & & \\
\hline WH6501 & & & & \\
\hline$\left(10^{-6} \mathrm{MFe}\right)$ & $\mathrm{N}: \mathrm{Fe}=2750$ & $5.5 \times 10^{-5}$ & & \\
\hline Several species & Fe $: P=10^{-1.4}$ to $10^{-27}$ & $3.8 \times 10^{-4}$ to $1.9 \times 10^{-5}$ & Maximum yield & Brand (1991) \\
\hline \multicolumn{5}{|l|}{ PCC 7002} \\
\hline$\left(10^{-5} \mathrm{MFe}\right)$ & - & $5.1 \times 10^{-3}$ & \multirow{2}{*}{ Ti(III)-citrate-EDTA } & \multirow{2}{*}{ Wilhelm et al. (1996) } \\
\hline$\left(10^{-9} \mathrm{MF} \in\right)$ & - & $1.5 \times 10^{-4}$ & & \\
\hline \multicolumn{5}{|l|}{ Eukaryotic algae } \\
\hline Thalassiosira oceanica & - & $2.0 \times 10^{-6}$ & Tl(III)-citrate-EDTA & Sunda et al (1991) \\
\hline Several species & Fe: $P=10^{-2}$ to $10^{-31}$ & $9.4 \times 10^{-5}$ to $7.4 \times 10^{-6}$ & Maximum yield & Brand (1991) \\
\hline
\end{tabular}


nisms. The first involves decreases in cellular iron quotients which allow cyanobacteria to exist more effectively at lower iron concentrations. The second involves the activation of iron-specific scavenging systems which allow the organism to compete for the limiting levels of iron in the environment. Evidence for both types of response exist and will be presented here in consideration of the potential role cyanobacteria may play in aquatic iron cycles.

\section{Iron-limited cyanobacterial physiology}

Perhaps the most obvious manifestation of iron limitation in cyanobacteria is chlorosis (Boyer et al. 1987). The specific changes associated with pigment content (and pigment absorption spectra) in coccoid cyanobacteria were first noted by Öquist $(1971,1974)$. These variations have since been confirmed in the freshwater isolate Anacystis nidulans R2 (Synechococcus sp. PCC 7942) as well as identified in the marine isolates Agmenellum quadruplicatum PR6 (Synechococcus sp. PCC 7002) and Synechococcus sp. WH 7803 (DC2) by a variety of researchers (Hardie et al. 1983a, Sherman \& Sherman 1983, Guikema \& Sherman 1984, Rueter \& Unsworth 1991, Wilhelm \& Trick 1995a). It has also been demonstrated that chlorophyll levels are affected by iron availability in marine filamentous Trichodesmium spp. (Rueter et al. 1990) and the freshwater filament Oscillatoria tenuis (Trick et al. 1995).

Due to the involvement of iron in the catalysis of pigment synthesis, the decrease in chlorophyll cell ${ }^{-1}$ as well as phycocyanin cell $1^{-1}$ seen in Anacystis nidulans and Agmenellum quadruplicatum was expected (Peschek 1979, Hardie et al. 1983a). Guikema \& Sherman (1984) demonstrated alterations induced by iron stress as an increase in the phycocyanin to chlorophyll ratio in $A$. nidulans $\mathrm{R} 2$, suggesting that some pathways may be more strongly affected than others. This has recently been confirmed in chemostat-cultured Synechococcus sp. PCC 7002 (Wilhelm \& Trick 1995a). Boussiba \& Richmond (1980) have suggested that the degradation of cellular phycocyanin may be only a secondary effect of iron limitation; nitrogen deficiency caused by a reduction in the level of iron-containing enzymes required for nitrogen assimilation may cause the cells to degrade phycocyanin pools and utilize them as a source of $\mathrm{N}$. Decreases have also been documented for cellular levels of the accessory pigments zeaxanthin and $\beta$-carotene (Wilhelm et al. 1996).

Decreases in cellular chlorophyll levels due to iron limitation have also been demonstrated in the natural environment. Murphy \& Lean (1975) demonstrated a decrease to one-third of the control level of chlorophyll in field studies of a freshwater system, and Paerl et al.
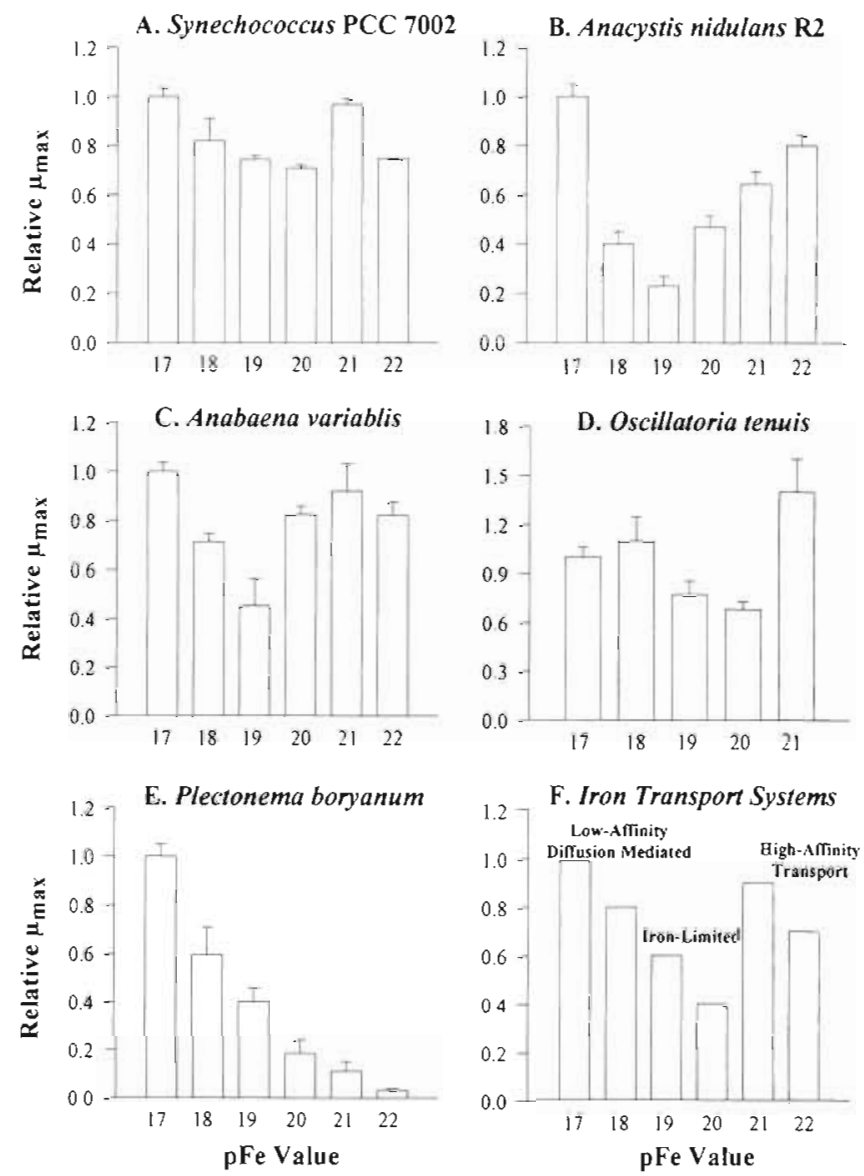

Fig. 1. Relative growth rates of cyanobacteria over a range of iron availabilities. Maximum growth rates $\left(\mu_{\text {nux }}\right)$ for cyanobacteria have been standardized to growth rates at the highest iron levels ( $\mathrm{pFe} 17 \approx 10^{-17} \mathrm{M}\left[\mathrm{Fe}^{3+}\right]$ ). Results demonstrate recoveries for growth in the siderophore-producing isolates (A) Synechococcus sp. PCC 7002 (Wilhelm et al. 1996), (B) Anacystis nidulans R2 (Kerry et al. 1988), (C) Anabaena variablis (Kerry et al. 1988) and (D) Oscillatoria tenuis (Brown \& Trick 1992) at low iron levels. (E) Plectonema boryanum, which does not produce any detectable siderophores, does not display this growth pattern (Kerry et al. 1988). (F) Predicted mechanisms of iron acquisition for the siderophoreproducing organisms

(1994) demonstrated an effect of iron availability on pigments in Trichodesmium spp. in marine environments.

Iron-limited growth has also been shown to cause specific changes in components of the electron transport chain. By culturing Aphanocapsa sp. 6714 at $10 \%$ of the control level of iron, Sandmann \& Malkin (1983) were able to bring about a switch from iron-containing ferredoxin to flavodoxin in the phytoplankton's electron transport chain. Further reduction in iron, to $1 \%$ of the control level, produced a reduction in all the ironcontaining photosynthetic redox proteins.

Iron deficiency leads to a number of physical changes in cyanobacteria. A size decrease in Anacys- 
tis nidulans R2 to between 33 and $50 \%$ of the ironsatiated cell length has been documented (Sherman \& Sherman 1983). Gorham et al. (1964) similarly showed a variation in size as well as a pronounced filament coiling in iron-deficient cultures of Anabaena flos-aquae. Electron microscopy has been used to identify a number of iron-deficiency-induced changes in intracellular morphology. A pronounced rearrangement of the thylakoids, culminating with their degradation as well as the degradation of the cytoplasmic membrane has been seen in Agmenellum quadruplicatum and $A$. nidulans (Hardie et al 1983b, Sherman \& Sherman 1983, Wilhelm 1994). A decrease in the number of cellular carboxysomes has been reported for $A$. nidulans (Sherman \& Sherman 1983) although no coordinate alteration has been seen in A. quadruplicatum (Hardie et al. 1983b). Similar analysis in the filamentous cyanobacterium Calothrix parientina showed no obvious changes in carboxysome formation during iron limitation although there was an unrelated formation of colourless, multicellular hairs and the development of false branching (Douglas et al. 1986).

Nitrogen fixation is perhaps the most 'iron-expensive' process within phytoplankton, and this Fe requirement forms the basis of arguments regarding the absence of significant populations of nitrogen-fixing phytoplankton in marine systems (Rueter et al. 1990, Hutchins 1995). An exception to this are the filamentous Trichodesmium spp., which fix nitrogen and are widely distributed in tropical and sub-tropical marine environments (Carpenter 1983). Direct evidence in both laboratory and field studies has linked the availability of $\mathrm{Fe}$ to $\mathrm{N}_{2}$-fixation in this cyanobacterium (Rueter et al. 1990, Paerl et al. 1994). This is supported by work that demonstrates iron deficiency causes a decrease in heterocyst formation in the nitrogen-fixing freshwater cyanobacterium Anabaena catenula (C. G. Trick pers. comm.).

Another set of changes often associated with low nutrient availablity is the production of stress-specific proteins in specific membrane or cell fractions. Factors such as salinity (Apte \& Bhagwat 1989), oxidative stress (Mittler \& Tel-Or 1991), heat shock (Borbely et al. 1985), as well as magnesium, calcium and phosphate limitation (Scanlan et al. 1989) have been shown to bring about the induction of specific proteins in cyanobacteria. Iron limitation has also been implicated as a potential inducer of protein production. Guikema \& Sherman (1984) noted the presence of an iron-limitation-inducible $34 \mathrm{kDa}$ protein in Anacystis nidulans, similar in size to an intracellular siderophore-transport protein found in Escherichia coli. The role of these proteins as potential ferrisiderophore-transport proteins will be discussed later.

\section{Siderophore production by cyanobacteria}

The ability of microorganisms to synthesize ironsequestering compounds (siderophores) and actively transport them into cells has been well studied in many bacterial and fungal systems, and the chemistry and behaviour of many of these chelators is now well understood (Crumbliss 1991). Siderophores (Greek: siderous $=$ iron, phorus $=$ bearer ) are low molecular weight (400 to $1200 \mathrm{Da}$ ), iron-binding compounds (siderophore $+\mathrm{Fe}^{3+}=$ a ferrisiderophore complex) which facilitate the transport of ferric ions into cells during periods of iron deficiency (Matzanke 1991). All aerobic and anaerobic bacteria and fungi, with the potential exceptions of Lactobacillus spp., Legionella spp., and Sacchromyces spp., appear to produce siderophores (Neilands \& Leong 1986). This includes microorganisms found in marine environments (Trick 1989, Reid et al. 1993). Siderophore production has also been seen in a limited number of microscopic eukaryotic phytoplankton (Trick et al. 1983, Benderliev \& Ivanova 1994).

The ability of cyanobacteria to produce siderophores has been known for some time. Estep et al. (1975), Murphy et al. (1976), and Simpson \& Neilands (1976) were among the first to demonstrate that cyanobacteria were capable of siderophore production during iron limitation (Table 2), while the best-studied system is that of schizokinen production by Anabaena sp. ATCC 27898 (Lammers \& Sanders-Loehr 1982, Goldman et al. 1983). Studies have demonstrated that many cyanobacterial species are capable of producing hydroxamate-type siderophores. These siderophores utilize hydroxamic acid moieties to coordinate iron molecules. While detection of these iron chelators has been quite common, detection of iron-chelating catecholate-type siderophores has only recently been reported (Brown \& Trick 1992, Wilhelm \& Trick 1994). Isolated catecholate siderophores from Synechococcus sp. PCC 7002 have been shown to have extremely high metal:ligand affinity constants $(\log K \approx 38.1$ to 42.3$)$, implying that they may play a significant role in the speciation of iron in aquatic systems (Lewis et al. 1995). The recovery in growth rate demonstrated for a number of cyanobacteria (Fig. 1) provides a strong correlation with the ability of these organisms to produce siderophores in batch culture conditions: Synechococ cus sp. PCC 7942, Anabaena variablis (Kerry et al. 1988), Synechococcus sp. PCC 7002 (Wilhelm \& Trick 1994 ) and Oscillatoria tenuis (Brown \& Trick 1992) have all been shown to produce siderophores.

It has been suggested that cyanobacterial iron acquisition in iron-replete environments is driven primarily by diffusion of $\mathrm{Fe}^{3+}$ along a diffusion gradient into the cells via porin channels in the outer membrane; thus 
decreases in iron concentrations should cause concomitant and proportional decreases in $\mu_{\max }$ (Wilhelm \& Trick 1994). In systems where no siderophores are found (i.e. Plectonema boryanum), $\mu_{\max }$ predictably decreases to zero as iron levels drop (Kerry et al. 1988). The presence of a siderophore-mediated high-affinity system changes the predicted growth rate in iron-limited cultures, with an increase in $\mu_{\max }$ being observed when the transport system is activated (Fig. 1).

\section{High-affinity transport systems}

The presence of a high-affinity iron-transport system in a microorganism is generally based on the identification of the specific components involved in siderophore-mediated iron transport. Transport of iron from ferrisiderophore complexes into cells requires membrane-associated, ferrisiderophore-specific proteins (Neilands 1994). These proteins are required in any membrane fraction or compartment into or through which the intact ferrisiderophore complex is transported. Neilands (1977) summarized the protein-mediated transport of a siderophore into enterobacteria in a model that is still the basis for iron transport in Gramnegative microorganisms. While most of these transport proteins are ferrisiderophore specific, some are exploited as channels for the assimilation or invasion of other components. Most notably, a number of lethal agents including the $\mathrm{T} 1$ and $\mathrm{T} 5$ viruses, colicin $\mathrm{M}$ and albomycin are incorportated into Escherichia coli via low-iron-induced outer membrane siderophore receptors (Neilands 1994).

The ability of cyanobacteria to produce transport proteins specific for siderophores remains to be demonstrated, although cyanobacteria have been shown to produce specific proteins during low iron availability (Guikema \& Sherman 1984, Scanlan et al. 1989, Trick et al. 1995). Ferrisiderophore-specific proteins would represent potential indicators of iron stress in natural systems. Work in several laboratories is now focussed on the purification of such proteins and the production of antibodies to them. These antibodies will provide an indication of iron-stress proteins in natural cyanobacterial communities, indicating that the organism may be in a low-iron environment (Wilhelm 1994, Hutchins 1995).

Although the production of extracellular siderophores by cyanobacteria is considered evidence for high-affinity iron transport, it remains to be determined whether cyanobacterial siderophores function to increase the affinity of cyanobacteria for iron. Siderophores have been demonstrated to increase the iron uptake rates of Synechococcus sp. PCC 7002

Table 2. Investigations of cyanobacterial siderophore production

\begin{tabular}{|c|c|}
\hline Conclusions & Source \\
\hline \multicolumn{2}{|l|}{ Marine } \\
\hline $\begin{array}{l}\text { Examination of cyanobacteria from nearshore waters. Produced a hydroxamate-type } \\
\text { siderophore }\end{array}$ & Estep et al. (1975) \\
\hline Survey of marine cyanobacteria. Most produced hydroxamate-type siderophores & Armstrong \& van Baalen (1979) \\
\hline $\begin{array}{l}\text { Examination of } 3 \text { strains of marine Synechococcus spp. (WH 6501, WH7803, WH8018). } \\
\text { No siderophores found }\end{array}$ & Rueter \& Unsworth (1991) \\
\hline Production of 4 siderophores by chemostat-grown Synechococcus sp. PCC 7002 & Wilhelm \& Trick (1995a) \\
\hline \multicolumn{2}{|l|}{ Marine and freshwater } \\
\hline $\begin{array}{l}\text { Siderophores from } 8 \text { coccoid and } 2 \text { filamentous cyanobacterial cultures. Both marine } \\
\text { and freshwater siderophore production. Catechol-type chelators common }\end{array}$ & Wilhelm \& Trick (1994) \\
\hline \multicolumn{2}{|l|}{ Freshwater } \\
\hline $\begin{array}{l}\text { Examined relationship between iron and nitrogen-fixing cyanobacterium. Found a } \\
\text { hydroxamate-type siderophore }\end{array}$ & Murphy et al. (1976) \\
\hline Isolated dihydroxamate-type siderophore from a Synechococcus sp. & Simpson \& Neilands (1976) \\
\hline Siderophore-mediated iron uptake in Anabaena sp. & Lammers \& Sanders-Loehr (1982) \\
\hline Production of schizokinen in Anabaena sp. & Goldman et al. (1983) \\
\hline Siderophore production and its effects on toxic copper & Clarke et al. (1987) \\
\hline Hydroxamates from Synechococcus sp. and Anabaena variablis & Kerry et al. (1988) \\
\hline Siderophore production in Rivulariaceae & Mahasneh (1991) \\
\hline Hydroxamates from Oscillatoria tenuis & Brown \& Trick (1992) \\
\hline Siderophores from Synechococcus sp. and Anabaena variablis & Trick \& Kerry (1992) \\
\hline
\end{tabular}


(Wilhelm \& Trick 1994). This neritic cyanobacterium, grown under iron-replete conditions, assimilates iron to the cytoplasm at a rate of $2.2 \mathrm{pM}_{\text {cell }}{ }^{1} \mathrm{~h}^{-1}$, almost an order of magnitude lower than iron-deficient cells when siderophores are present (19.0 $\mathrm{pM} \mathrm{cell}^{-1} \mathrm{~h}^{-1}$ ). These rates bracket those determined in studies of the maximum iron-assimilation rates of a natural population of pelagic marine Synechococcus spp. (9.2 pM cell $^{-1} \mathrm{~h}^{-1}$ ) (Wells et al. 1994). Although siderophores have been shown to increase assimilation rates, at this point in time the effect of siderophores on cellular iron affinity can only be inductively inferred (Wilhelm \& Trick 1994).

It is thus important to distinguish between high'affinity' and high-'velocity' iron uptake. Studies on the effect of siderophores on cyanobacterial iron acquisi-

A Simplified Aquatic Iron Cycle

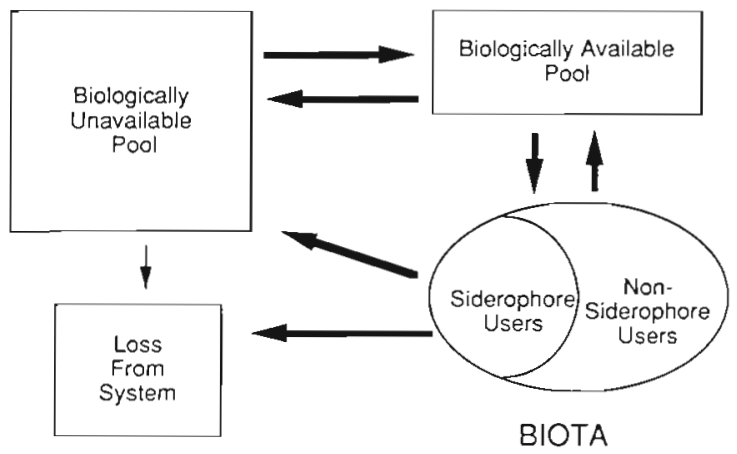

B Effect of Siderophores on the Aquatic Iron Cycle

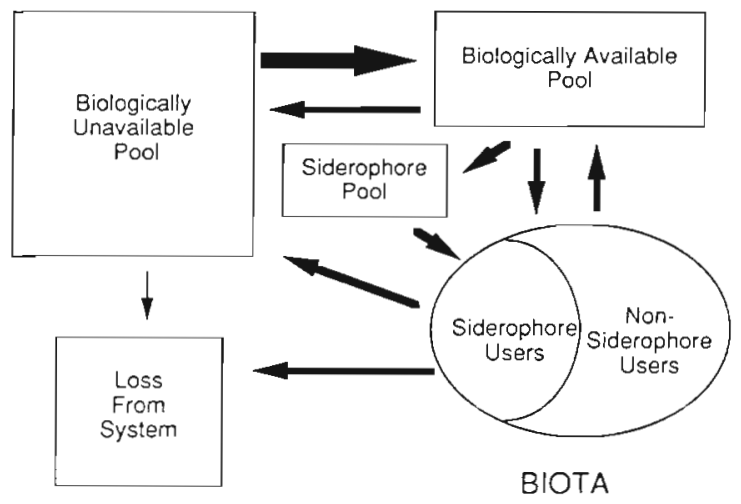

Fig. 2. Potential effect of siderophores on the biological availability of iron in aquatic systems. (A) Simplified iron cycle, demonstrating flux of uron from biologically unavailable pool out of the system and to biota via a biologically available pool. The biologically available pool is a sum of all the different species of tron which are biologically accessible to phytoplankton in the system. (B) The introduction of siderophores forces an increase in biologically available iron, while organically chelated iron, originally from the biologically available pool, remains available to siderophore users. Pool sizes not to a specific scale tion have examined only uptake velocities, and such changes do not demonstrate changes in cellular affinity since higher velocity uptake does not necessarily mean higher affinity for a substrate (Wilhelm \& Trick 1994). The affinity of a system is a reflection of that system's attractiveness for the nutrient in question. Highaffinity nutrient-transport systems are thus those systems within organisms which, when induced, will increase the organisms' ability to utilize the pool of the nutrient within the environment. Typically, these systems are investigated by applying Michaelis-Menten kinetics to substrate-limited nutrient-transport data. For iron, however, regulating substrate concentrations is arduous, and thus affinity changes must be implied through other means. Speciation in the environment often renders the majority of iron biologically unavailable to organisms utilizing conventional diffusionmediated iron-acquisition systems, which must rely on the low concentrations of free ferric ions (provided from other inorganic sources) in the environment to satiate their needs. If an organism is to utilize the biologically unavailable pool of iron in the system, it must change its ability to attract iron so as to increase its ability to scavenge it. A high-affinity iron-acquisition system may therefore be defined as any inducible system which allows organisms access, either directly (through utilization) or indirectly (by changing the speciation of extracellular Fe), to the pool of biologically unavailable iron. These systems may ultimately lead to higher velocities of nutrient transport but are not defined alone by the increase in transport velocity. The specifics of how this pool may be accessed by cyanobacteria are discussed below.

\section{Role of microbial iron chelators in aquatic systems}

The extent to which siderophores affect the cycling of iron in aquatic systems has yet to be determined. Recent reports have suggested that much of the dissolved iron in some marine systems is complexed by low molecular weight organics of unknown form and function which are similar in size and stability constants to siderophores produced by eubacteria (Gledhill \& van den Berg 1994, Rue \& Bruland 1995, Wu \& Luther 1995). If these compounds are indeed siderophores, they can be expected to dramatically alter the predicted availability of iron in aquatic systems by both direct and indirect mechanisms (Fig. 2). Since large amounts of iron in the system are partitioned to the biologically unavailable pool, organisms are often forced to compete for the small portion which becomes biologically available through rapid conversion from inorganic species. Siderophores in the system would further scavenge Fe which is already available in the 
environment. This results in a shift from insoluble $\mathrm{Fe}(\mathrm{OH})_{3}$ (s) to $\mathrm{Fe}(\mathrm{OH})_{2}{ }^{+}$, which may rapidly interconvert with $\mathrm{Fe}^{3+}$ (Zafiriou \& True 1980) and renders $\mathrm{Fe}$ available at a rate sufficient to maintain the available Fe pool at a constant size (Hudson \& Morel 1990). Thus, in the presence of siderophores, the pool of biologically available iron is indirectly increased by the amount of iron that is complexed by the siderophores. The utilization of the previously biologically unavailable iron is of importance to the ecosystem as a whole as it increases the amount of iron in the biological iron cycle and iron which may ultimately be available to the other organisms in the system via recycling through grazing and microbial systems (Hutchins \& Bruland 1995). This concept is in marked contrast to the conclusions of Murphy et al. (1976), who thought siderophores were produced by cyanobacteria in order to provide a competitive advantage over other algae during iron stress, as these other plankton could not utilize the organically complexed iron. While this possiblity cannot be refuted, one must now also consider the possibility that siderophore production is simply a 'survive at all cost' response to low iron availability and that the extreme costs in terms of cellular stores and energy are offset by the potential for survival (Trick et al. 1995). Moreover, if siderophore producers exclusively utilize organically complexed iron, then the static biologically available Fe pool should be more available to the fewer organisms drawing from it.

The question also remains as to the factors which have driven the evolution of high-affinity transport in aquatic systems. Many authors have argued that there is little practicality in the production of cyanobacterial siderophores from an energetics perspective (Hutchins et al. 1991) and that only populations, not individuals, can benefit from siderophore production on an ecosystem scale (Hutchins 1995). This has led to suggestions that cyanobacteria may exist which are capable of using siderophores produced by other organisms, thereby avoiding the energetic and material costs of siderophore production (Hutchins 1995). While siderophore auxotrophs have been isolated in terrestrial heterotrophic bacterial communities, and are commonly utilized as bioassay organisms for the presence of specific siderophores (Neilands \& Nakamura 1991), similar cyanobacteria remain to be isolated from aquatic systems.

\section{CONCLUSION}

In the last 2 decades, picoplankton have been demonstrated to be of critical importance in the cycling of nutrients through marine systems. Since the function of iron as a limiting nutrient has been reconsid- ered, we are now forced to examine these issues with respect to each other. Exhaustive efforts to determine the role of iron in the regulation of productivity in aquatic systems continue. The resolution of a variety of issues, including the identification of the source(s) of iron-complexing organics, the efficacy of iron recycling, and the identity of biologically available Fe in aquatic systems, is required before we can effectively resolve these systems. In addition, an understanding of the role of prochlorophytes in the aquatic iron cycle (for which there is little published information) will add to our knowledge of how the other major group of photosynthetic picoplankton is influenced by iron availability. While recent evidence from IronEx suggests that prochlorophytes may not be iron limited (Martin et al. 1994), the lack of axenic cultures has made laboratory studies of their iron physiology difficult (Chisholm et al. 1992).

Global carbon cycles are affected strongly by the factors that affect aquatic primary productivity. Mounting evidence now suggests that many regions of the world's oceans are indeed iron-limited and that unique strategies for survival are undertaken by the species that exist in these systems. If the responses of cyanobacteria and other siderophore producers to low-iron stress are capable of altering the bioavailability of iron to the aquatic community, then these systems require further serious and critical examination.

Acknowledgements. Thanks go to $\mathrm{Dr}$ C. G. Trick for assistance and support in the development of these ideas. I also thank D. A. Hutchins, E. L. Rue and B. L. Lewis for providing prepublication manuscripts. C. A. Suttle, M. G. Weinbauer, D. A. Hutchins and an anonymous reviewer greatly improved the manuscript through discussions and their comments, and J. Rooker and B. A. Sudeyko assisted in preparation. This is contribution no. 958 of the Marine Science Institute.

\section{LITERATURE CITED}

Apte SK, Bhagwat AA (1989) Salinity-stress induced proteins in two nitrogen-fixing Anabaena strains differentially tolerant to salt. J Bacteriol 171:909-915

Armstrong JE, Van Baalen C (1979) Iron transport in microalgae: the isolation and biological activity of a hydroxamate siderophore from the blue-green alga Agmenellum quadruplicatum. J gen Microbiol 111:253-262

Benderliev KM, Ivanova NI (1994) High-affinity siderophoremediated iron transport system in the green alga Scenedesmus incrassatulus. Planta 193:163-166

Biederman G, Schindler P (1957) On the solubility product of precipitated iron (III) hydroxide. Acta Chem Scand 11. $731-740$

Borbely G, Suranyi G, Korcz A (1985) Effect of heat shock on protein synthesis in the cyanobacterium Synechococcus sp. strain PCC 6301. J Bacteriol 161:1125-1130

Boussiba S, Richmond AE (1980) C-phycocyanin as a storage protein in the blue-green alga Spirulina platensis. Arch Microbiol 125: 143-147 
Boyer GL, Gillam AH, Trick CG (1987) Iron chelation and uptake. In: Fay P, Van Baalen C (eds) The Cyanobacteria Elsevier, New York, p 415-436

Brand LE (1991) Minimum iron requirements of marne phytoplankton and the implications of biogeochemical control of new production. Limnol Oceanogr 36 $1756-1771$

Brown CM, Trick CG (1992) Response of the cyanobacterium Oscillatoria tenuis, to low iron environments: the effect on growth rate and evidence for siderophore production Arch Microbiol 157:349-354

Carpenter EJ (1983) Nitrogen fixation by marine Oscillatoria (Trichodesmium) in the world's oceans. In: Carpenter EJ Capone DG (eds) Nitrogen in the marine environment. Academic Press, New York, p 65-103

Clarke SE, Stuart J, Sanders-Loehr J (1987) Induction of siderophore activity in Anabaena spp. and its moderation of copper toxicity. Appl environ Microbiol 53:917-922

Chavez FP, Buck KR, Coale KH, Martin JH, DiTullio GR Welschmeyer NA, Jacobson AC, Barber RT (1991) Growth rates, grazing, sinking, and iron limitation of equatorial Pacific phytoplankton. Limnol Oceanogr 36: 1816-1833

Chisholm SW, Frankel SL, Goericke R, Olson RJ, Palenik B Waterbury JB, West-Johnsrud L, Zettler ER (1992). Prochlorochoccus marinus nov. gen. nov. sp.: an oxyphototrophic prokaryote containing divinyl chlorophyll $a$ and $b$ Arch Microbiol 157:297-300

Crumbliss AL (1991) Aqueous solution equilibrium and kinetic studies of iron siderophore and model siderophore complexes. In: Winkelmann G (ed) CRC handbook of microbial iron chelates. CRC Press, Boston, p 177-234

DiTullio GR, Hutchins DA, Bruland KW (1993) Interaction of iron and major nutrients controls phytoplankton growth and species composition in the tropical North Pacific Ocean. Limnol Oceanogr 38:495-508

Douglas D, Peat A, Whitton BA (1986) Influence of iron status on structure of the cyanobacterium (blue-green alga) Calothrix parientina. Cytobios 47:155-165

Estep M, Armstrong JE, Van Baalen C (1975) Evidence for the occurrence of specific iron(III)-binding compounds in near-shore marine ecosystems. Appl Microbiol 30 $186-188$

Geider RJ, La Roche J (1994) The role of iron in phytoplankton photosynthesis, and the potential for iron-limitation of primary productivity in the sea. Photosynth Res 39 $275-301$

Gledhill M, van den Berg CMG (1994) Determination of complexation of iron (III) with natural organic complexing ligands in seawater using cathodic stripping voltammetry. Mar Chem 47:41-54

Goldman SJ, Lammers PJ, Berman MS, Sanders-Loehr J (1983) Siderophore-mediated iron uptake in different strains of Anabaena sp. J Bacteriol 156:1144-1150

Gorham PR, McLachlan JL, Hammer UT, Kim UK (1964) Isolation and culture of toxic strains of Anabaena flos-aquae (Lyngb.). Verh int Verem theor angew Limnol 15:796-804

Guikema JA, Sherman LA (1984) influence of iron deprivation on the membrane composition of Anacytis nidulans. Plant Physiol 74:90-95

Hardie LP, Balkwill DL, Stevens SE Jr (1983a) Effects of iron starvation on the physiology of the cyanobacterium Agmenellum quadruplicatum. Appl environ Microbiol 45: $999-1006$

Hardie LP, Balkwill DL, Stevens Jr SE (1983b) Effects of iron starvation on the ultrastructure of the cyanobacterium Agmenellum quadruplicatum. Appl environ Microbiol 45: $1007-1017$
Hudson RJM, Morel FMM (1989) Distinguishing between extra- and intracellular iron in marine phytoplankton. Limnol Oceanogr 36:1113-1120

Hudson RJM, Morel FMM (1990) Iron transport in marine phytoplankton: kinetics of cellular and medium coordination reactions. Limnol Oceanogr 35:1002-1020

Hutchins DA (1995) Iron and the marine phytoplankton community. Prog Phycol Res (in press)

Hutchins DA, Bruland KW (1995) Fe, Zn, Mn and N transfer between size classes in a coastal phytoplankton community: trace metal and major nutrient recycling compared. J mar Res 53:297-313

Hutchins DA, Rueter JG, Fish W (1991) Siderophore production and nitrogen fixation are mutually exclusive strategies in Anabaena 7120. Limnol Oceanogr 36:1-12

Kerry A, Laudenbach DL, Trick CG (1988) Influence of iron limitation and nitrogen source on growth and siderophore production by cyanobacteria. J Phycol 24:566-571

Lammers PJ, Sanders-Loehr J (1982) Active transport of ferric schizokinen in Anabaena sp. J Bacteriol 151:288-294

Lewis BL, Holt PD, Taylor SW, Wilhelm SW, Trick CG, Butler A, Luther GW III (1995) Voltametric estimation of iron (III) thermodynamic stability constants for catecholate siderophores isolated from marine bacteria and cyanobacteria. Mar Chem 50:179-188

Mahasneh IA (1991) Siderophore production in the Rivulariaceae, blue-green alga (cyanobacteria). Microbios 65: $97-103$

Martin JH et al. (1994) Testing the iron hypothesis in ecosystems of the equatorial Pacific Ocean. Nature 371:123-129

Martin JH, Fitzwater SE (1988) Iron deficiency limits phytoplankton growth in the north-east Pacific subarctic. Nature 331:341-343

Martin JH, Gordon RM, Fitzwater SE (1990) Iron in Antarctic waters. Nature 345:156-158

Martin JH, Gordon RM, Fitzwater SE, Broenkow WW (1989) VERTEX: phytoplankton/iron studies in the Gulf of Alaska. Deep Sea Res 36:649-680

Matzanke BF (1991) Structures, coordination chemistry and functions of microbial iron chelates. In: Winkelmann $G$ (ed) CRC handbook of microbial iron chelates. CRC Press, Boston, p 15-64

Mittler R, Tel-Or E (1991) Oxidative stress responses and shock proteins in the unicellular cyanobacterium Synechococcus R2 (PCC 7942). Arch Microbiol 155:125-130

Murphy TP, Lean DRS (1975) The distribution of iron in a closed ecosystem. Verh int Verein Limnal 19:258-266

Murphy TP, Lean DRS, Nalewajko C (1976) Blue-green algae: their excretion of iron-selective chelators enables them to dominate other algae. Science 192:900-902

Neilands JB (1977) Siderophores: biochemical ecology and mechanism of 1 ron transport in Enterobacteria. Adv Chem Ser $1.62: 1-32$

Neilands JB (1994) Effect of iron deprivation on outer membrane protein expression. Meth Enzymol 235:344-352.

Neilands JB, Leong SA (1986) Siderophores in relation to plant growth and disease. A Rev Plant Physiol 37:187-208

Neilands JB, Nakamura K (1991) Detection, determination, isolation, characterization, and regulation of microbial iron chelates. In: Winkelmann $\mathrm{G}$ (ed) Handbook of microbial chelates. CRC Press, Boston, p 1-14

Öquist G (1971) Changes in plant composition and photosynthesis induced by iron-deficiency in the blue-green alga Anacystis nidulans. Plant Physiol 25:188-191

Öquist $G(1974)$ Iron deficiency in the blue-green alga Anacystis nidulans: changes in pigmentation and photosynthesis. Plant Physiol 30:30-37 
Paerl HW, Prufert-Bebout LE, Guo C (1994) Iron-stimulated N2 fixation and growth in natural and cultured populations of the planktonic marine cyanobacteria Trichodesmium spp. Appl environ Microbiol 60:1044-1047

Peschek GA. (1979) Nitrate and nitrite reductase and hydrogenase in Anacystis nidulans grown in $\mathrm{Fe}$-and Mo-deficient media. FEMS Microbiol Lett 6:371-374

Reid RT, Live DH, Faulkner DJ, Butler A (1993) A siderophore from a marine bacterium with an exceptional ferric ion stability constant. Nature 366:455-457

Rue EL, Bruland KW (1995) Complexation of iron (III) by naturally organic ligands in the central North Pacific as determined by a new competitive equilibration/adsorptive cathodic stripping voltametric method. Mar Chem 50; $117-138$

Rueter JG, Onki K, Fujita Y (1990) The effect of iron nutrition on photosynthesis and nitrogen fixationn in cultures of Trichodesmium (Cyanophyceae). J Phycol 26:30-35

Rueter JG. Unsworth NL (1991) Response of marine Synechococcus (Cyanophyceae) cultures to iron nutrition. J Phycol $27: 173-178$

Sandmann G, Malkin R (1983) Iron-sulfur centers and activities of the photosynthetic electron transport chain in irondeficient cultures of the blue-green alga Aphanocapsa. Plant Physiol 73:724-728

Scanlan DJ, Mann NH, Carr NG (1989) Effect of iron and other nutrient limitations on the pattern of outer membrane proteins in the cyanobacterium Synechococcus PCC7942. Arch Microbiol 152:224-228

Sherman DM, Sherman LA (1983) Effect of iron deficiency and iron restoration on ultrastructure of Anacystis nidulans. J Bacteriol 156:393-401

Simpson FB, Neilands JB (1976) Siderochromes in cyanophyceae: isolation and characterization of schizokinen from Anabaena sp. J Phycol 12:44-48

Sunda WG, Swift DG, Huntsman SA (1991) Low iron requirement for growth in oceanic phytoplankton. Nature 351 : $55-57$

Trick CG (1989) Hydroxamate-siderophore production and utilization by marine eubacteria. Curr Microbiol 18: $375-378$

Trick CG, Andersen RJ, Gillam A, Harrison PJ (1983) Proro-

Responsible Subject Editor: S. W. Chisholm, Cambridge, Massachusetts, USA centrin: an extracellular siderophore produced by the marine dinoflagellate Prorocentrum minimum. Science 219:306-308

Trick CG, Kerry A (1992) Isolation and purification of siderophores produced by cyanobacteria, Synechococcus $5 \mathrm{p}$. 7942 and Anabaena variablis ATCC 29413. Curr Microbiol 24:241-245

Trick CG. Wilhelm SW (1995) Physiological changes in the coastal manne cyanobacterium Synechococcus sp. PCC 7002 exposed to low ferric ion levels. Mar Chem 50: $207-217$

Trick CG, Wilhelm SW, Brown CM (1995) Pigmentation, protein expression and photosynthetic capacity of the cyanobacterium Oscillatoria tenuis, grown under low iron conditions. Can J Microbiol 41 (in press)

Wells ML, Price NM, Bruland KW (1994) Iron limitation and the cyanobacterium Synechococcus in equatorial Pacific waters. Limnol Oceanogr 39:1481-86

Wells ML, Price NM, Bruland KW (1995) Iron chemistry in seawater and its relationship to phytoplankton: a workshop report. Mar Chem 48:157-182

Wilhelm SW (1994) Ecological aspectes of iron acquisition in Synechococcus sp. (Cyanophyceae). PhD thesis, The University of Western Ontario, London

Wilhelm SW, Maxwell DP, Trick CG (1996) Growth, iron requirements and siderophore production in iron-limited Synechococus PCC 7002 . Limnol Oceanogr 41(2) (in press)

Wilhelm SW, Trick CG (1994) Iron-limited growth of cyanobacteria: multiple siderophore production is a common response. Limnol Oceanogr 39:1979-1984

Wilhelm SW, Trick CG (1995a) Phyisological profiles of Synechococcus in iron-limiting continuous culture. J Phycol 31 . $79-85$

Wilhelm SW, Trick CG (1995b) Effects of vitamin $B_{12}$ concentration on chemostat cultured Synechococcus PCC 7002. Can J Microbiol 41:145-151

Wu J, Luther GW (1995) Complexation of iron(III) by natural organic ligands in the Northwest Atlantic Ocean by a competitive ligand equilibrium method and a kinetic approach. Mar Chem 50:159-177

Zafiriou OC, True MB (1980) Interconversion of iron (III) hydroxy complexes in seawater. Mar Chem 8:281-288

Manuscript first received: August 7, 1995

Revised version accepted: November 6, 1995 